\title{
Legeerklæring ved arbeidsuførhet - skjema til besvær
}

\author{
Legeerklæringen ved arbeidsuførhet er ment å gi svar på om folketrygdlovens krav til årsakssammenheng \\ mellom sykdom og uførhet er oppfylt. Vi har tidligere hevdet at kvaliteten på legenes erklæringer i uføresaker \\ er varierende og at skjemaene ofte er mangelfullt utfylt. Forklaringen kan delvis være at Nav-skjemaets tekst \\ og format er et lite egnet redskap for legen i arbeidet med uføresaker.
}

Guri Aarseth

guri.aarseth@medisin.uio.no

Bård Natvig

Eivind Engebretsen

Anne Helene Kveim Lie

Når pasienten reiser krav om uførpensjon, må legen skrive erklæring, men skjemaene er ofte mangelfullt utfylt (1). En av artikkelforfatterne (GA) er praktiserende allmennlege og arbeider med en doktorgrad med tittelen En undersøkelse av språket $i$ legeerklceringer ved uførhet. Denne kronikken er blant annet ment som et konstruktivt forslag til endring av den kanskje viktigste rammebetingelsen for legeerklæringene - nemlig skjemaet NAV 08-07.08 av 1999/2010.

Ved hjelp av M. Hallidays språkvitenskapelige teoretiske fundamentet, «systemisk funksjonell lingvistikk», undersøker vi hvordan skjemaet Legeerklcering ved arbeidsuførhet skaper mening med de språklige valgene som er gjort, hvordan dette kan tenkes å påvirke legens besvarelse og hvilke mulige valg som kan gjøres for å få andre typer svar fra legen (2).

\section{Sjanger og format}

Det finnes ganske klare sjangerkrav til attester fra helsepersonell. Disse er i detalj penslet ut $i$ en forskrift til lov om helsepersonell, noe som må forstås i lys av slike teksters betydning for samfunnet og for individets rettssikkerhet (3). Nav er gitt fullmakt til å bestemme hvilke opplysninger legeerklæringen skal inneholde og i hvilken orden. Hensikten med skjemaformatet er altså å disiplinere og organisere legens besvarelse.

Vår erfaring er imidlertid at skjemaet Legeerkloering ved arbeidsuførhet ikke har en slik effekt. Legens tekst bryter hyppig den orden som skjemaet legger opp til. Eksempler på dette er når legen gir et inadekvat svar (f.eks. gir anamnestiske opplysninger under punkt 2.6, status presens) eller kommer med en anbefaling om å tilstå uføretrygd i stedet for å beskrive trygdesøkerens funksjonsevne. Liknende funn er gjort av Kiessling og medarbeidere når det gjelder svenske legeerklæringer. De hevder blant annet at det i $27 \%$ av erklæringene var så mangelfulle opplysninger at det ikke var mulig å bedømme hvorvidt nedsatt funksjon påvirket arbeidsevnen (4).

\section{Uklare spørsmål gir uklare svar}

Mange har erfart at det ofte kan være vanskelig å fylle ut skjemaer. Uklare spørsmål gir lett uklare svar. Nav-skjemaet er hierarkisk bygd opp - med diagnosen(e) som utgangspunkt. De medisinske opplysningene henter legen fra pasientjournalen. Dette er som regel ukomplisert skrivearbeid, der klipp-og-lim-metoden benyttes ganske ofte.

Vanskelighetene starter fra og med punkt 5 , der legen skal sette sykdommen i sammenheng med funksjonsevnen og arbeidsevnen. De kulminerer i det viktige punkt 7, der legen blir bedt om å «anslå hvor stor betydning funksjonsnedsettelsen har for at arbeidsevnen er nedsatt». Underlig nok er dette spørsmålet plassert et annet sted i skjemaet, løsrevet fra punkt 5.1, der man ber om en beskrivelse av hvordan sykdommen svekker funksjonsevnen. Sammenhengen mellom arbeidsevnen og funksjonsevnen undersøkes ikke nærmere. I skjemaet hopper man i stedet til behandling av arbeidsevnen (punkt 6), noe som neppe kan sies å være legens anliggende. Innholdet i punkt 7 kunne i stedet ha vært en umiddelbar fortsettelse av punkt 5.1, for eksempel ved at legen blir bedt om på medisinsk basis å vurdere om pasienten, med nedsatt funksjonsevne, eventuelt kan være $\mathrm{i}$ arbeid.

H.M. Solli har vist at svaralternativene ja/nei under punkt 5.3 gjør det mulig for legen å konkludere implisitt om nedsatt arbeidsevne, uten krav om begrunnelse, og han hevder at dette kan skape vilkårlighet i vedtakene (5). Vi vil bemerke at «implisitt» ikke betyr at premissene for konklusjonen ikke finnes, men at de er usagte forutsetninger som ikke fremkommer i teksten. Mottakeren må ha en viss kompetanse i både medisin og teksttolking for å få med seg de underforståtte premissene og sammenhengene. Generelt mener vi at inferens (fortolkning av det usagte) eller implikatur (slutninger som er intendert fra senderens side, men ikke direkte uttalt) åpner for vilkårlighet og i liten grad bør forekomme i forvaltningssaker (6).

\section{Åpne eller lukkede spørsmål?}

Selv om forskriften setter regler for innholdet, formen og stilen i en legeerklæring, har både Nav og legen stor frihet til å gjøre sine språklige valg. Som vi skal se innebærer dette at man dermed signaliserer mening. Vi vil hevde at skjemaets språkbruk og format i seg selv er en hindring for å kunne beskrive kompleksiteten og legens tvil i uføresaker.

Den relativt lave statusen som utfylling av legeerklæringer for trygden synes å ha blant fastleger, forsterkes trolig av at det på følgende viktige spørsmål ikke gis andre svarmuligheter enn ja eller nei: «Bør NAV vurdere om det er en yrkessykdom?» (punkt 2.7), «Vil pasienten kunne gjenoppta det tidligere arbeidet?» (punkt 5.3a), «Vil pasienten kunne ta annet arbeid?» (punkt $5.3 b)$ og «Antas behandlingen å føre til bedring av arbeidsevnen?» (punkt 6a).

Hva er det som er problematisk med disse spørsmålene? Det viktigste er at lukkede spørsmål (ja/nei-spørsmål) er polariserende, mens virkeligheten er full av nyanser, forbehold og usikkerhet (2). Uten forutgående klare premisser og utfyllende opplysninger fremstår legens valg av kategoriske ja/nei-«konklusjoner» som lite annet enn innholdsløse manøvre for å få uførekabalen til å gå opp.

Mellommenneskelig kommunikasjon er i virkeligheten full av modalitet, uttrykk for nyanser: tendens, mulighet, sannsynlighet og nødvendighet (2). Modalitet er en sterk relasjonell kraft mellom sender og mottaker og uttrykker avsenderens holdninger og evalueringer (7). Det er Nav - ikke legen - 


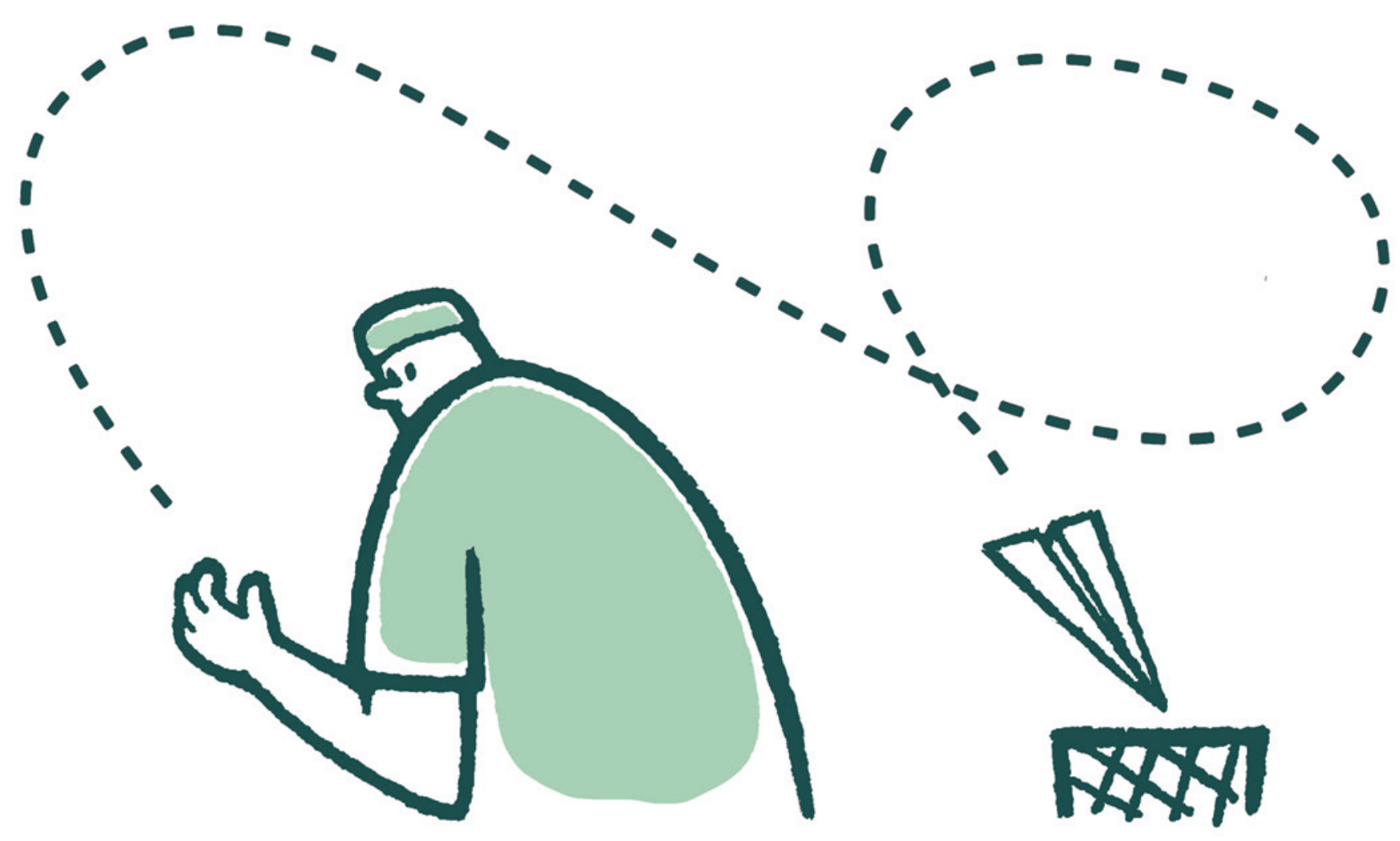

Illustrasjon @ Superpop

som avgjør om pasienten fyller kravene til uførhet. Derfor er det naturlig at legens tvil og usikkerhet utgjør en del av premissgrunnlaget.

Dette kommer tydelig frem i forskrift om krav til helsepersonells attester: «Dersom det er knyttet tvil eller usikkerhet til attesten eller erklæringens faktiske grunnlag, vurderinger eller konklusjon, skal dette fremgå ...» (§ 5) (3). Det er derfor et poeng at nyanser og tvil fremkommer eksplisitt, ikke pakket inn som ikke-avgitte eller irrelevante svar eller skråsikre utsagn. Vi foreslår at Nav vurderer å stryke sine ja/nei-spørsmål fra skjemaet og i stedet stille åpne, såkalte hv-spørsmål (hvordan, hva, hvorfor osv.). Slike spørremåter åpner for at legen i større grad kan anvende sin brede kjennskap til pasientens helse og livssituasjon til å beskrive og tydeliggjøre sammenhenger i teksten.

\section{Språket i Nav-skjemaet påvirker legens tekst i uønsket retning} I dagens Nav-skjema, Legeerklocring ved arbeidsuførhet, legges det språklig vekt på begrensninger $i$ arbeidsevne. Dette må være i utakt med folketrygdloven $\S 12-5$ tredje ledd, der det heter: «Oppmerksomheten må rettes mot hva den enkelte kan gjøre, til tross for den medisinske lidelsen.»
Som vi alt har påpekt, oppfordres legen merkelig nok ikke til å beskrive funksjonsmuligheter hos pasienten. I stedet blir legen kun bedt om å opplyse «hvordan funksjonsevnen generelt er nedsatt på grunn av sykdom» (punkt 5.1) - «Hva kan pasienten ikke (markert av Nav) gjøre i det nåværende arbeidet?» (punkt 5.4) og «oppgi begrensninger i forhold til tiltak» (punkt 4). Her er det klare føringer i Nav-teksten for legen til å vektlegge det negative.

Typiske eksempler på svar på disse spørsmålene er: «klarer i praksis ingen former for jobb uten smerter» og «pasienten er $100 \%$ arbeidsufør». Den første påstanden savner full troverdighet fordi den mangler modalitet. I tillegg overlater den til leseren selv å tolke sammenhengen mellom arbeid og smerter og har som premiss at man ikke kan jobbe med smerter, noe de fleste arbeidstakere faktisk gjør (8). Forklaringen uteblir og er heller ikke etterspurt i skjemaet. Det andre svaret er tautologisk, dvs. at utsagnet bruker konklusjonen (som det er Navs oppgave å fatte) som premiss, og det gir derfor ingen meningsfull informasjon til saksbehandleren.

Punkt 5.1 («beskriv hvordan funksjonsevnen generelt er nedsatt på grunn av sykdom») legger føringer for legen til å beskrive pasientens funksjonsevne som nærmest ikke-eksisterende. Selv om spørre- formen til en viss grad åpner for forklaring og utdyping, er den uheldig - i skjemaet stilles det her et krav om at funksjonstapet skal være generelt nedsatt. Kapitel 12 i folketrygdloven krever imidlertid at funksjonsnedsettelse skal være hovedårsaken til nedsatt arbeidsevne, at den skal skyldes sykdom, være vesentlig nedsatt og varig, men ikke generell.

Skjemaets imperativ om å beskrive det generelle tapet av funksjon savner ikke bare grunnlag i lovverket, det er også lite realistisk, siden det jo må omfatte alle områder av livet. Uttrykket er lite operativt, og forsøk på å sannsynliggjøre en slik tilstand vil neppe fremstå som troverdige. Derimot er det av interesse å se hvordan legen tekstmessig forsøker å tilfredsstille et slikt krav: Det vi ofte observerer, er at svaret blir nettopp - generelt, i betydningen lite spesifisert («konstante smerter i hele kroppen», «sammensatt sykehistorie», «kronisk sliten» osv.).

\section{Pasienten blir borte i teksten}

Uavhengig av de forskriftsbaserte sjangerkravene til Legeerkloering ved arbeidsuførhet er det vårt inntrykk at legene i praksis har etablert en egen konvensjon for skrivemåten. Vi finner som regel en intern medisinsk sjargong holdt i telegramliknende stil, med bruk av forkortelser 
som vanligvis ikke forekommer i det norske språk. Forkortelser som i eksemplet «A EKG N» (arbeids-EKG normalt) vil neppe være forståelig for en saksbehandler i Nav.

Vi ser også en omfattende bruk av nominalisering («innleggelse» for å legge inn), passive verb (følges opp, behandles osv.), metonymier («institusjon» for ansvarlig behandler og «hjerteinfarktet» for pasienten) og fravær av subjekt eller personlig pronomen («hodeløse» setninger).

Hva betyr slike språklige grep for fremstillingen av pasientens virkelighetsverden? Effekten er blant annet at metonymiene, «hjerteinfarktet», ikke pasienten, blir temaet i teksten. «Innleggelser» er en nominalisering (av handlingen å legge inn) som pakker inn informasjon (når? hvor? hvor lenge?) og utelater aktører (hvem la inn?). «Følges opp» er passiv handling (følges opp av hvem?). Hvilken eventuell aktiv rolle spiller pasienten her? Andre språklige grep i denne sjangeren er å fjerne subjektet fullstendig («Behandlet for psykose», «Avsluttet tiltaket» o.1.)

Felles for alle disse språkvalgene er at de virker depersonifiserende og fremmedgjørende. Denne språklige økonomiseringen ser ut til å ha blitt etablert som et eget sjangertrekk i legeerklæringene. Det ligger nær å anta at skrivemåten er påvirket av legens oppdragsgiver, skjemateksten, idet også den preges av samme språkbruk. Et eksempel på nominalisering fra skjemateksten er: «Ny vurdering av tidligere utrednings-/behandlingsplan» (punkt 3.4), der nominaliseringer (substantivering av handlingene vurdere, behandle og utrede) fordunkler setningens mening. Er den et spørsmål? En konstatering? Et underforstått imperativ? I så fall - er den et spørsmål om resultatet av slik nyvurdering, et krav til legen om å foreta en ny vurdering nå eller senere, eller kan legen selv bestemme om det skal gjøres? Skal den nye vurderingen gjøres av andre (f.eks. spesialister)? Selv $i$ en kjent kontekst som et uføreskjema blir meningen med setningen uklar.

Tekster som inneholder metonymier (ombenevninger), passive verb og nominalisering kan ses som levninger fra vitenskapelig artikkel-sjangeren, der depersonifisering og bruk av metonymier er ment å gi inntrykk av generaliserbarhet og objektivitet (9). De er imidlertid lite egnet til å beskrive en enkeltpersons helse og funksjon. Her vil effekten av slik språkbruk være annerledes.

La oss som eksempel se på hvordan Navskjemaet bruker metonymier. «Funksjonsevne», «arbeidsevne» og «funksjonsnedsettelsen» brukes flere steder som om dette er størrelser vi kan betrakte atskilt fra pasienten, for eksempel i «Anslå hvor stor betydning funksjonsnedsettelsen har for at arbeidsevnen er nedsatt» (punkt 7) og «Anslå varigheten av den nedsatte arbeidsevnen».

Vi ser at tekniske Nav-begreper farger tenkningen rundt pasienten. Subjektet er, ifølge Halliday, det «ansvarlige leddet i setningen». Fravær av personlig pronomen som subjekt, passivisering (gjennom verbformen) og bruk av metonymier representerer noen av de sterkeste depersonifiserende effektene i teksten, ifølge lingvisten G. Rundblad (10). I tillegg bærer de bud om å tone ned ansvaret hos både legen og pasienten, nettopp på grunn av språkbrukens distanserende og fremmedgjørende effekt. En slik bruk av språket er lite samsvarende med intensjonene i teksten: Hvis man med «funksjonsevne» sikter til personens samlede evne til aktivitet og deltakelse, vilje, motivasjon og kompetanse, burde personen først og fremst innta rollen som subjekt i erklæringen.

\section{Fritekst versus skjematekst}

De fleste leger velger å benytte Nav-skjemaet når de skriver uføreerklæringer, men noen få velger å skrive erklæringen som fritekst. Spesialisterklæringer, derimot, er nesten uten unntak nedskrevet som fritekst, selv om mange benytter en mal. Vårt inntrykk er at friteksterklæringene oftere er utformet på en måte som åpner for nyanser og legens vurderinger, drøftinger og tvil.

De er mindre preget av den telegramstilen som er vanlig ved utfyllingen av uføreskjemaet, og legens vurderende og ansvarlige jeg er mer til stede $i$ fritekst.

Samtidig blir pasienten i større utstrekning personifisert ved å være et eksplisitt subjekt - i større grad enn selve sykdommen er pasienten temaet i den språklige utformingen. Andre aktører (legen, terapeuten) benevnes oftere ved navn i stedet for ved metonymiene «poliklinikken», «sykehuset» osv. I fritekstene brukes hyppigere de små, men viktige ordene (konjunksjoner og adverb) som bidrar til sammenheng i fremstillingen, som for eksempel og, mens, fordi, da, derfor, av denne grunn osv. Dette i motsetning til i skjemaet, der slike elementer er fjernet til fordel for en tro på skjemaets automatiske ordnende effekt.

Vi har ikke holdepunkter for å hevde at spesialisterklæringene i fritekst er vesentlig bedre enn fastlegenes skjemaerklæringer når det gjelder beskrivelse av funksjonsog arbeidsevne, men premissene i friteksterklæringene gir etter vår erfaring et bedre grunnlag for å vurdere dem. Dette underbygges av en tidligere sammenliknende undersøkelse (11). Nav bør vurdere om ikke friteksterklæringer fra fastleger bør erstatte dagens ineffektive skjema, uten at dette bør være til hinder for å kreve svar på konkrete spørsmål.

\section{Konflikt nedfelt i teksten}

Mange leger opplever portvaktrollen (kontrollfunksjonen) i trygdesaker som en uriaspost der den faglige integriteten er under press. Gulbrandsen og medarbeidere har vist at det å utøve portvaktrollen er forbundet med nedsatt trivsel hos legene og at nesten halvparten av dem setter sitt eget skjønn til side for å etterkomme pasientens ønske $(12,13)$.

Vi antar at legens opplevelse av press mot den faglige integriteten, kombinert med kravet til saklighet og dokumentasjon ved arbeidsuførhet, kan være konfliktfylt. Det er videre grunn til å anta at dette gjenspeiles i legens tekst, for eksempel i form av for lite informasjon, irrelevante opplysninger, uklarheter og mangel på dokumentasjon. I tillegg er det kanskje også en konflikt mellom to kulturer: Mens legens mål ideelt sett er å behandle eller lindre for å bedre helse, funksjon og sykdomsmestring, spør Nav om behandlingen «antas å føre til bedring av arbeidsevnen» (punkt 6a).

Språkbruken skaper et inntrykk av at nedsatt arbeidsevne kan behandles medisinsk, på linje med sykdom, avkledd det personlige og sosiale aspektet. Pasienten som hel, integrert person oppløses i teksten, og vi står tilbake med «arbeidsevnen». Arbeidsuførhet betraktet som et medisinsk problem reflekterer en enkel biomedisinsk sykdomsmodell som er utilstrekkelig for å kunne gi et nyansert bilde av arbeidsuførhetens årsak (5).

Vi spør oss om også dette kan ha betydning for hvordan leger fyller ut skjemaet. Å støtte seg utelukkende på «objektive funn» vil i de færreste tilfeller føre til at pasienten innvilges uføretrygd, fordi slike objektive funn som oftest er fraværende. Manglende kliniske opplysninger (status presens) i skjemaet og funksjonsbeskrivelser med uklare grenser mellom trygdesøkerens utsagn og legens vurdering kan være måter for legen å omgå problemet på. Den språklige effekten av Nav-skjemaet er at pasienten blir borte i vrimmelen av uheldige språklige valg og dermed ikke vurderes som et aktivt, ansvarlig og helt subjekt.

\section{Konklusjon}

Vi har i denne kronikken rettet oppmerksomheten mot Nav-skjemaet Legeerklcering ved arbeidsuførhet. Det synes å fungere mot sin hensikt, som er å avklare viktige spørsmål ved uførhet, fordi det i liten grad treffer sin mottaker - legen. Formatet og språket svekker muligheten for gode legeerklæringer preget av bredt og åpent skjønn, de åpner snarere for utydelighet og pulverisering av ansvar. 
Det er dessuten vår oppfatning at språkbruken flere steder er på kant med både intensjonene i lovverket og synet på individ-helse-arbeid som en integrert enhet. Det er rimelig å anta at konflikten kommer til syne i legenes tekster i form av brudd på sjangerkravene og store avvik fra intensjonen med skjemaet - orden og struktur.

\section{Guri Aarseth (f. 1951)}

er spesialist i allmennmedisin, fastlege og rådgivende overlege i Nav. Hun har en mastergrad i Art in Literature and Medicine fra King's College i London og er stipendiat ved Institutt for allmennmedisin, Universitetet i Oslo.

Forfatter har fylt ut ICMJE-skjemaet og oppgir følgende interessekonflikter: Hennes ph.d.prosjekt er støttet av FARVE (forskning for arbeid og velferd, www.nav.no/Farve).

\section{Bård Natvig (f. 1955)}

er dr.med. og professor i allmennmedisin ved Institutt for helse og samfunn, Universitetet i Oslo.

Forfatter har fylt ut ICMJE-skjemaet og oppgir følgende interessekonflikter: Han har et enkeltpersonforetak som rådgivende lege i forsikrings- og trygdemedisin.

\section{Eivind Engebretsen (f. 1974)}

er professor dr.art. og forskerutdanningskoordinator ved Institutt for helse og samfunn,

Universitetet i Oslo.

Forfatter har fylt ut ICMJE-skjemaet og oppgir ingen interessekonflikter.

\section{Anne Helene Kveim Lie (f. 1969)}

er dr.med. og førsteamanuensis ved Avdeling for samfunnsmedisin, Institutt for helse og samfunn, Universitetet i Oslo.

Forfatter har fylt ut ICMJE-skjemaet og oppgir ingen interessekonflikter.

\section{Litteratur}

1. Aarseth G, Lie AH, Natvig B. Hvordan står det til med legeerklæringene? Tidsskr Nor Legeforen 2012: 132: 2148-9.

2. Halliday MAK, Matthiessen C. An Introduction to functional grammar. 3. utg. London: Hodder Education, 2004.

3. Forskrift om krav til helsepersonells attester erklæringer ol. 2008. http://lovdata.no/dokument/ SF/forskrift/2008-12-18-1486 (25.11.2013)

4. Kiessling A, Arrelöv B, Larsson A et al. Quality of medical certificates issued in long-term sick leave or disability in relation to patient characteristics and delivery of health care. Scand J Public Health 2013; 41: 412-20

5. Solli HM, da Silva AB, Lie RK et al. Biomedisinsk sykdomsmodell og rettferdig fordeling av uførepensjon. Tidsskr Nor Lægeforen 2005: 125 3293-6.
6. Grice P. Studies in the way of words. Cambridge, MA: Harvard University Press, 1989: 22-40.

7. Maagerø E. Språket som mening. Innføring i funksjonell lingvistikk for studenter og lærere. Oslo: Universitetsforlaget, 2005

8. Kjeldsberg M, Tschudi-Madsen H, Dalen I et al. Symptom reporting in a general population in Norway: results from the Ullensaker study. Scand J Prim Health Care 2013; 31: 36-42.

9. Thompson G. Introducing functional grammar. Oxon: Routledge, 2014

10. Rundblad G. Impersonal, general, and social: the use of metonymy versus passive voice in medical discourse. Writ Commun 2007; 24: 250-77.

11. Evaluering av fors $\emptyset \mathrm{k}$ med bruk av legespesialister og rådgivende leger i uføresaker. SINTEF-rapport 257. Oslo: SINTEF, 2006.

12. Gulbrandsen P. Førde R, Aasland OG. Hvordan har legen det som portvakt? Tidsskr Nor Lægeforen 2002: 122: 1874-9.

13. Gulbrandsen P, Aasland OG, Førde R. Legeattester for å hjelpe pasienten. Tidsskr Nor Lægeforen 2004; 124: 192-4

Mottatt 27.8. 2013, første revisjon innsendt 7.11. 2013, godkjent 25.11. 2013. En av forfatterne er redaktør i Tidsskriftet. Manuskriptet er derfor behandlet eksternt av en uavhengig redaktør. Magne Nylenna. 